\title{
腎移植後患者に対し腹腔鏡下卵巣腫瘍摘出術を施行した2例
}

独立行政法人国立病院機構千葉医療センター 産婦人科 ${ }^{1} 、$

千葉大学大学院医学研究院 生殖医学 ${ }^{2}$ 、藤田医科大学医学部 移植・再生医学 ${ }^{3)}$ 木下亜希 ${ }^{1)}$ 、石川博士 ${ }^{2)}$ 、剣持 敬 $^{3)}$ 、岡嶋祐子 ${ }^{1)}$

\section{Two cases of laparoscopic surgery for the treatment of ovarian tumor following kidney transplantation}

\author{
Aki Kinoshita $^{1)}$, Hiroshi Ishikawa ${ }^{2)}$, Takashi Kenmochi ${ }^{3)}$, Yuko Okajima ${ }^{1)}$ \\ Department of Obstetrics and Gynecology, National Hospital Organization Chiba Medical Center ${ }^{1)}$, \\ Department of Reproductive Medicine, Graduate School of Medicine,Chiba University ${ }^{2}$, \\ Department of Transplantation and Regenerative Medicine, Fujita Health University ${ }^{3)}$
}

\begin{abstract}
Along with the rise in kidney engraftment rates the number of women who are candidates for gynecologic laparoscopic surgery after a kidney transplantation has increased. Although kidney function may be maintained within operable range in these women, characteristic complications caused by the dislocation of the transplanted kidney and immunosuppression are risks for surgery. We report two cases of women with ovarian tumors, who underwent laparoscopic surgery following kidney transplantation. We performed laparoscopic bilateral adnexectomy for a 58 -yearold postmenopausal woman with serous cystadenofibroma arising from both ovaries, and laparoscopic cystectomy for a 30-year-old woman with a left ovarian endometrial cyst. We adjusted the laparoscopic port placement to the location of the transplanted kidney, and administered perioperative immunosuppressive drugs and antibiotics in consultation with the renal transplantation specialists. Postsurgical hospital stay was 4 days and no complications were observed in both women. Minimally invasive surgery, such as laparoscopic surgery, is suitable for women after kidney transplantation because of better perioperative infection control. Considerations should be made for dislocations of transplanted kidneys and ureters, and it is critical for primary physicians to be familiar with immunosuppressive medications, their side effects
\end{abstract}

Key words: kidney transplantation, laparoscopic surgery, benign ovarian tumor.

\section{【緒 言】}

末期腎不全患者に対する移植患者は本邦で近年 増加傾向にあり、2018年は1865人に腎移植が施行 されている。腎移植の生着率は1980年から1990年 代にかけてのシクロスポリン等カルシニューリン 阻害薬の導入により徐々に改善し、2000年の代謝 拮抗薬のミコフェナール酸モフェチルの導入によ り、2001年以降飛躍的に改善した。2010～2017年 の生体腎移植生着率は移植 1 年後 $98.4 \% 、 5$ 年後 $94.1 \%$ となっている ${ }^{1,2)}$ 。

腎移植件数の増加と移植腎の生着率の向上に伴
い、腎移植後の患者が婦人科疾患の手術適応とな る機会が増えていると考えられる。移植腎は一般 的に右側の腸骨窩に移植されることが多く、通常 腎よりも肥大しているため、腹腔鏡手術用卜ロカ ールを挿入する際に損傷しないように注意が必要 である。また移植腎につながる尿管は膀胱と新吻 合で接続されており、その走行は通常と異なる。 さらに腎移植後は長期間の免疫抑制剂服用に伴う 易感染状態であり、周術期管理において感染予防、 免疫抑制剂の使用方法、特性、副作用について習 熟する必要がある。

今回われわれは卵巣腫瘍を有する生体腎移植後 
の患者に対して腹腔鏡下手術を 2 例施行したの で、その周術期管理と腹腔鏡下手術の留意点につ いて考察し報告する。な㧍本症例報告の論文化に 際して、患者の同意を得ている。

\section{【症例 1】}

患者 : 58歳、 5 妊 3 産、46歳閉経、身長 $154 \mathrm{~cm}$ 、 体重54 kg

主訴：下腹痛

既往歴：47歳で慢性腎不全のため血液透析導入と なり、57歳で他院にて生体腎移植が施行されてい た。

内服薬：シクロスポリン $7 \mathrm{mg}$ 、ミコフェノール 酸モフェチル1000mg、プレドニゾロン $5 \mathrm{mg} 、 ラ$

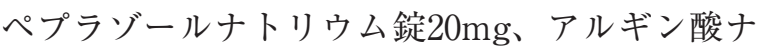
トリウム液 $5 \% 45 \mathrm{ml}$ 、スルファメトキサゾール (400mg) トリメトプリム $(80 \mathrm{mg})$ 錠 1 錠、アス ピリン100mg、エチゾラム錠 $1 \mathrm{mg}$ 、クエン酸第

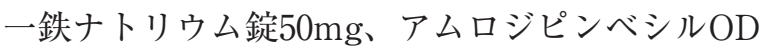
錠 $5 \mathrm{mg}$ 、ロキソプロフェンナトリウム水和物錠 $60 \mathrm{mg}$

現病歴：57歳時に下腹部痛が出現し、痛みが持続 するため内科を受診し、CTにて両側卵巣腫瘍を 指摘された。同年に生体腎移植が施行され、その 後は無症状で卵巣腫瘍は経過観察となっていた。 腎移植の翌年より腫瘍が徐々に増大したため、58 歳で他院移植外科より当科に紹介された。初診時 の超音波検查にて両側卵巣に多房性腫瘍を認め た。MRIで子宮後方にT2強調画像で高信号を示 す、隔壁肥厚や充実性部分のない両側卵巣多房性 囊胞性腫瘤を認めた（左：長径 $6 \mathrm{~cm}$ 、右：長径 $5 \mathrm{~cm}$ )（図 1 )。腫瘍マーカーはCA125 $9.5 \mathrm{U} / \mathrm{ml}$ CA19-9 69.2 U/mlであった。以上より増大傾向に
ある良性卵巣腫瘍と診断し、腹腔鏡下手術を施行 した。なお、術前検查ではBUN15.9mg/dl、血清 クレアチニン $0.96 \mathrm{mg} / \mathrm{dl}$ と腎機能は保たれていた。 手術所見 : 全身麻醉下に腹腔鏡下両側付属器摘出 術を施行した。術前の画像検査から移植腎が右腸 骨窩、後腹膜腔に位置していたため、移植腎を避 けるように、臍部に $5 \mathrm{~mm}$ 、左下腹部に $11 \mathrm{~mm}$ 、 左臍高側腹部に $5 \mathrm{~mm}$ のポートを留置し左パラレ ル法 3 孔式で施行した（図 2 )。臍部より腹腔鏡 を挿入し気腹すると、移植腎による腹膜の膨隆を 確認することができた。移植腎を損傷しないよう に注意しながら、卵巣堤索をLigasure ${ }^{\circledR}$ (コヴィ ディエンジャパン株式会社、日本）で処理し、再 側の付属器を切除した。摘出した両側付属器は工 ンドパウチ ${ }^{\circledR}$ (製造販売業社：ジョンソンエンド ジョンソン株式会社製造業者 ETICON ENDO-SURGERY、INC 米国) を用いて左下腹 部のポートから回収した（図 3 写真 1 、図 4 写 真 2 )。手術時間は47分、術中出血量は少量であ った。本症例では後腹膜腔を展開しなかったため、 尿管の走行は確認していない。

手術前に前医の移植外科医からの助言を得て、 抗生剂投与量と免疫抑制剂の内服方法を決定し た。抗生剤は手術前にSBT/ABPC $3 \mathrm{~g}$ 、手術後に $\mathrm{SBT} / \mathrm{ABPC} 3 \mathrm{~g}$ を投与するのみとし、免疫抑制剤 (シクロスポリン $7 \mathrm{mg}$ 、ミコフェノール酸モフェ チル $1000 \mathrm{mg}$ ）は手術当日朝まで通常通り内服を 継続し、術後は手術当日のみ休薬とし、翌日朝よ り再開した。また、移植腎の微小循環維持目的に 内服していたアスピリンは術前10日前から休薬と し、術後 2 日目より内服を再開した。術後疼痛は 少なく鎮痛薬の投与は必要とせず、翌日から食事 と歩行を開始し、術後 4 日目に退院となった。摘

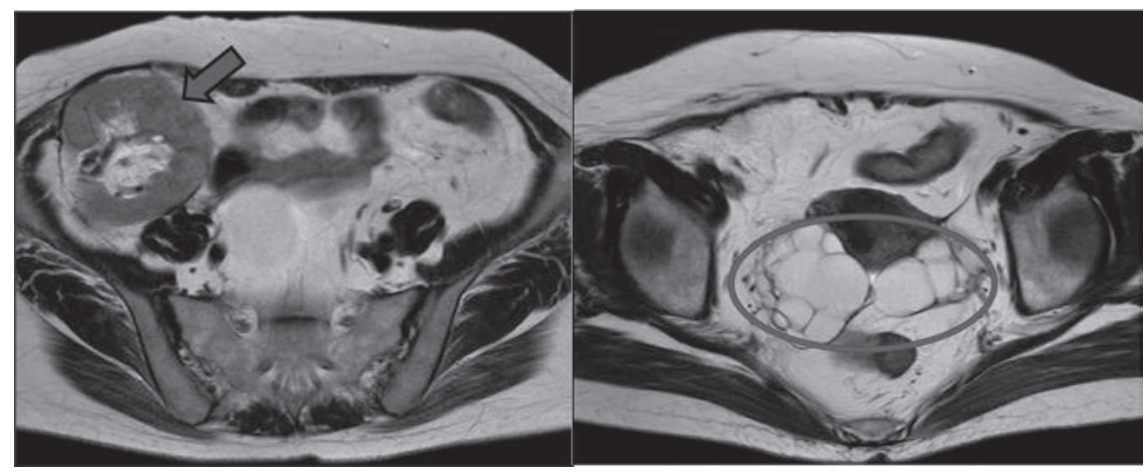

図1 症例 1 MRI所見

右）右腸骨窩に移植腎（矢印）を認めた。左）子宮後方にT2強調画像で高信号を示す、両側 卵巣に多房性腫瘍（左卵巣：長径 $6 \mathrm{~cm}$ 、右卵巣：長径 $5 \mathrm{~cm}$ ) を認めた。 


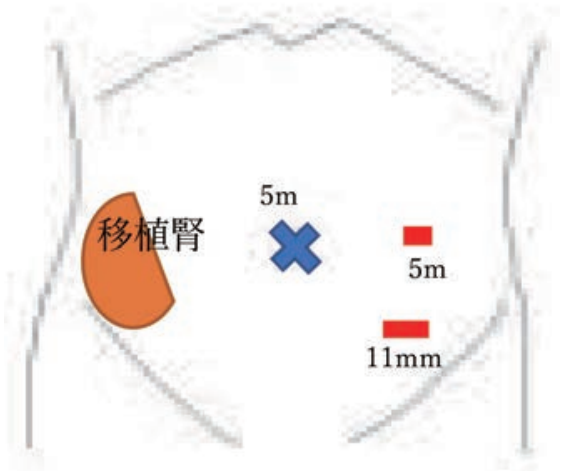

図2

店例1のポートの配置

右腸骨窩の移植腎を避けるように、臍部に $5 \mathrm{~mm}$ 、左下腹部に $11 \mathrm{~mm}$ 、左臍高側腹部に $5 \mathrm{~mm}$ のポートを留置し左パラレル法3 孔式で施行した。

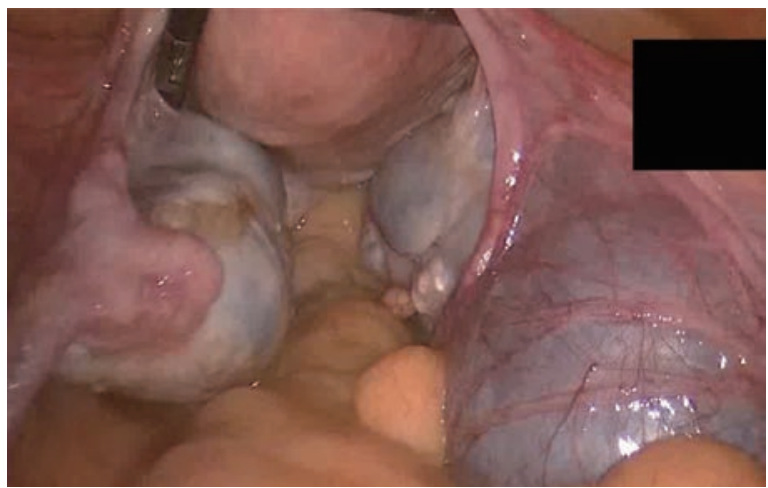

図3 写真 1 症例 1 腹腔鏡所見

両側卵巣多房性腫瘍に対し腹腔鏡下両側附属器切除を施行し た。Ligasure ${ }^{\circledR}$ を使用し両側附属器を切除した後エンドパウチ 内に収納し内容液を吸引後腫瘍を左下腹部切開創より摘出し た。

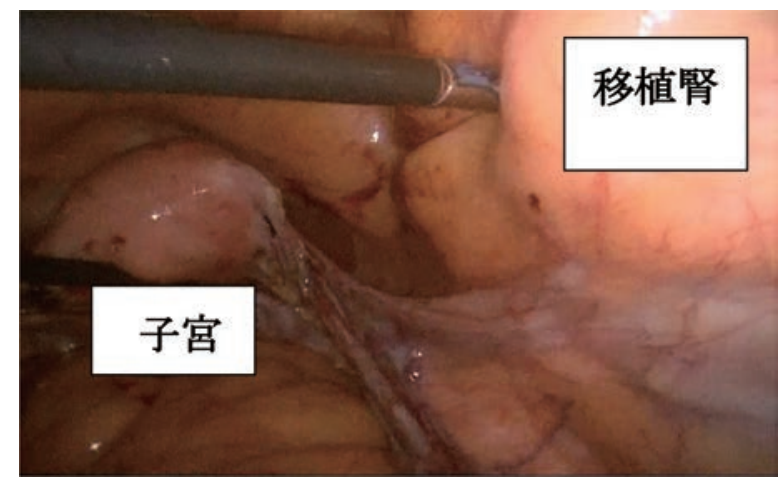

図4 写真2 症例 1 腹腔鏡所見

両側付属器切除後の所見。右上方（右腸骨窩, 腹膜外）に移 植腎は位置している。
出物の病理診断は両側卵巣の漿液性囊胞線維腺腫 であった。婦人科手術より術後 7 年経過して移植 腎の機能も保持されており著変なく経過している。

\section{【症例2】}

患者：30歳 0 妊 0 産 既婚 身長 $156 \mathrm{~cm}$ 体重 $48 \mathrm{~kg}$

主訴：特になし

既往歴：14歳でIgA腎症を発症し、27歳で腎不全 のため血液透析導入となり、29歳で生体腎移植が 施行されていた。

月経歴：初経14歳 月経周期28日型、持続 7 日、 整 月経困難あり

内服薬：タクロリムス水和物 $7 \mathrm{mg}$ 、ミコフェナ ール酸モフェチル1000mg、プレドニゾロン錠 5

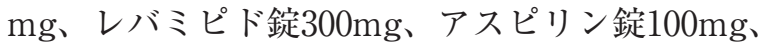
アルギン酸ナトリウム液 $5 \% 45 \mathrm{ml}$ 、スルファメ トキサゾール $(400 \mathrm{mg})$ トリメトプリム $(80 \mathrm{mg})$ 錠 1 錠、ラフチジン錠 $10 \mathrm{mg}$ 、ピラロゾン系解熱 鎮痛消炎配合剂顆粒 $3 \mathrm{~g}$

現病歴：腎移植術前の精査中に腹部CTにて骨盤 腔に腫瘤を指摘され、29歳で症例 1 と同じ他院移 植外科より当科に紹介された。超音波検査、MRI にて $6 \mathrm{~cm}$ 大の左卵巣チョコレート襄胞を認めた。 内診所見では子宮、左付属器の可動性は不良であ り、左下腹部に圧痛を伴っていたが、緊急性はな いと判断し、腎移植後に腹腔鏡下手術を行う方針 とした。前医にて移植腎の機能を評価しながら、 チョコレート襄胞の経過観察は 3 か月ごとに行 い、30歳で腹腔鏡下手術を施行した。術前検査で は血清クレアチニン $1.60 \mathrm{mg} / \mathrm{dl} 、$ BUN $16.4 \mathrm{mg} / \mathrm{dl}$ と軽度の上昇を認めたが手術可能な腎機能は保た れていた。

手術所見：全身麻酔下に腹腔鏡下左卵巣腫瘍核出 術および内膜症癒着剥離術を施行した。右側の移 植腎を避けるように、臍部に $5 \mathrm{~mm}$ 、下腹部に左 に $11 \mathrm{~mm}$ 、下腹部正中に $5 \mathrm{~mm}$ 、やや内側寄りの 右下腹部に $5 \mathrm{~mm}$ のポートを留置しダイヤモンド 法で施行した（図 5 )。気腹後、移植腎による右 下腹部の膨瘤を確認した。腫大した左卵巣および 正常の右卵巣を確認した。子宮と左付属器は癒着 しており、ダグラス窩は癒着により閉鎖していた。 腹腔鏡下に左チョコレート襄胞の内容を穿刺し、 左卵巣と子宮周囲の癒着を剥離後、チョコレート 囊胞を核出した。本症例では後腹膜を展開してお らず、尿管の走行は確認していない。手術時間は 195分、術中出血は少量であった。移植外科医の 


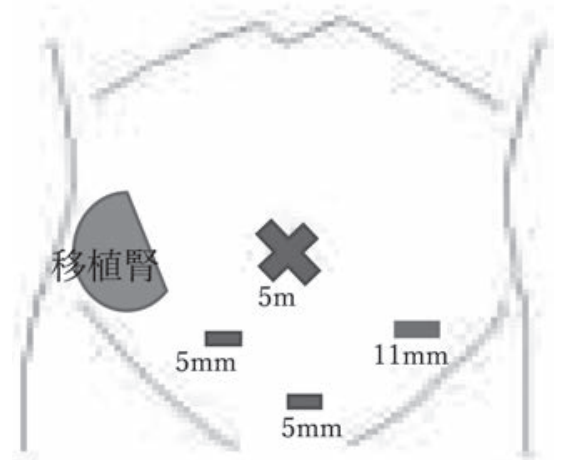

図5

症例2のポートの配徝

右腸骨窩の移植腎を避けるように、臍部に $5 \mathrm{~mm}$ 、下腹部に左 に $11 \mathrm{~mm}$ 、下腹部正中に $5 \mathrm{~mm}$ 、やや内側寄りの右下腹部に $5 \mathrm{~mm}$ のポートを留置しダイヤモンド法で施行した。

指示により術前後の抗生剂は当日のみ、SBT/ $\mathrm{ABPC} 1.5 \mathrm{~g}$ 、手術後にSBT/ABPC1.5g と通常の半 量投与とした。免疫抑制剤（タクロリムス水和物 $7 \mathrm{mg}$ およびミコフェナール酸モフェチル 1000mg）は手術当日朝まで内服を継続し、手術 後は当日のみ休薬とし、翌日朝より内服を再開し た。症例 1 と同様、手術前10日から中止したアス ピリンの内服は術後 2 日目から再開した。術後、 鎮痛剂は使用せず経過し、翌日より食事および歩 行開始とし、経過良好ため術後 4 日目に退院とな った。摘出物病理組織診断は内膜症性囊胞であっ た。術後ホルモン療法等の追加治療は行わず、 7 年間チョコレート囊胞の再発は認めていない。

\section{【考察】}

腎移植後の患者は移植腎の拒絶反応予防のため に生涯を通じて数種類の免疫抑制剂の内服を継続 する必要がある。したがって、そのような患者の 周術期管理では、その易感染性と免疫抑制剤の副 作用に留意しなければならない。腎移植後に使用 する新規免疫抑制剂の特徵として、微量で強力な 薬理効果を発揮する反面、有効治療域が狭いため、 血中濃度を一定に保つため内服コンプライアンス の遵守が重要である ${ }^{3)}$ 。また移植腎の保護のため にも薬剤の腎毒性を考慮し、抗菌剂や鎮痛剂など の薬片投与を少なくすることが望ましい。今回は 術前に腎移植外科医と連絡を取りながら、婦人科 手術を施行する上での適切な時期を調整し、術前 の腎機能に見合った薬剤の投与量や投与法につい ての検討を行なった。腎移植後の手術では、免疫 抑制剤を術後も休薬しない事が原則とされる。消 化器外科の術後で数日間内服ができない場合で は、静注投与や胃管から投与した報告がある ${ }^{4)}$ 。
今回、我々は移植外科医と協議し、 2 症例ともに 術前に明らかな移植腎腎機能の異常がみられなか ったことより、免疫抑制剂は手術当日の夕の 1 回 のみの休薬とし、静注投与への変更は行わなかっ た。また、腎移植後は移植腎サイズとレシピエン 卜体重により血清クレアチニン值が変化するた め、血清クレアチニン值で腎機能障害を評価する ことは困難とされる。そのため抗生剤の投与量に ついては、個々の症例の移植腎機能を評価して調 整されることが一般的である。症例 2 では腎機能 は良好に保たれているものの臨床経過から、移植 外科の指示により抗生剂は通常の半量投与とした が、術後感染症は発症しなかった。これは、腹腔 鏡下手術では開腹手術に比べて創部が小さいため 創部感染のリスクが低く、また腹腔内感染も起こ りにく(5) ためと考えられる。また経口摂取の開 始と離床は翌日に可能であり、鎮痛剤は使用せず に術後早期の退院が可能であった。腎移植後の患 者には、低侵襲で感染リスクの少ない腹腔鏡手術 が適しているといえる。

腎移植後の免疫抑制療法は多剂併用が原則であ り、今回の症例で使用されていた免疫抑制剂はシ クロスポリン、タクロリムス水和物、ミコフェノ ール酸モフェチルであった。これらの免疫抑制剂 は以下に述べる様な特徵および副作用がある。

シクロスポリンおよびタクロリムス水和物は、 カルシニューリン阻害薬の代表的なものである。 シクロスポリンは1982年より導入されたT細胞抑 制薬であり、腎毒性や神経毒性、高血圧、高脂血 症、消化器症状、多毛、歯肉障害などの副作用が ある。特に腎毒性には注意が必要であり、免疫抑 制効果を期待できる血中濃度と腎毒性が出現する 中毒域との差が小さいため、薬物動態を正確に評 価することおよび定期的な腎機能評価は必須とさ れる。また長期使用による悪性腫瘍の発生にも注 意が必要である。タクロリムス水和物は、1996年 より導入されたT細胞抑制薬であり、シクロスポ リンよりは腎機能障害を引き起こしにくいとされ る。また他の免疫抑制剤と比較し骨髄機能に影響 を与えることなく、強力に免疫を抑制する作用を 有している。留意すべき副作用としては、中枢神 経系障害 (可逆性後白質脳症症候群、高血圧性脳 症)、高血糖 (NODAT移植後発症糖尿病)、心不 全、不整脈 心筋障害、悪性腫瘍などがある ${ }^{6)}$ 。 ミコフェノール酸モフェチルは2000年より導入さ れた代謝拮抗薬であり、腎機能を含め重篤な臟器 障害を生じず、催癌作用も少ない免疫抑制剂であ 
る。投与に際して血中免疫グロブリン低下、高尿 酸血症、白血球減少症、汎血球減少症、リンパ腫、 消化性潰瘍などの副作用報告 ${ }^{4)}$ があり下㾥などの 症状が強い時は中止し、ミゾリピンやアザチオプ リンなどの薬剤のへ変更が必要である7?。

腎移植後の腹腔鏡下手術においては、移植腎を 損傷しないように腹腔鏡手術用ポートを作成する 必要がある。移植腎は一般的には右腸骨窩の後腹 膜下に位置する（図 6 )。右腸骨動脈と腸骨静脈 が左側より浅い位置にあり血管吻合が容易であ り、血栓症が少ないというメリットがあるためで ある。ただし 2 回目の移植や膵・腎同時移植では 左腸骨窩に移植する場合もある。移植腎の動脈、 静脈はそれぞれ内腸骨動脈、外腸骨静脈に吻合し、 尿管を膀胱の粘膜下に埋め込み吻合するため、移 植尿管は通常の尿管の走行とは異なる位置へ変化 することになる ${ }^{8)}$ 。このため移植腎、尿管の位置 の変化により移植腎側の付属器周囲の視野が悪く なり手術操作が困難となることがある。さらに、 吻合血管や移植尿管、移植腎の損傷を来さないよ うにポートの位置や術中の鉗子の操作に留意する 必要がある。ポート挿入時の移植腎の損傷を避け る工夫として、今回の 2 症例では移植腎を術前に MRIで確認したうえで移植腎を避けるようにポー 卜を配置した。他にポート挿入時の臟器損傷を避 けるために、臍部からの単孔式で手術を施行した 症例報告がみられる ${ }^{9,10)}$ 。

手術適応のある多様な腎移植後の症例に対し、 合併症の発生を予防し手術を完遂するために周術 期に様々な工夫がなされている。腎移植後の腹腔 鏡下子宮悪性腫瘍手術では、移植腎と腸骨血管の 吻合部位の損傷を回避しなければならない。その ために術前にCTや尿管ステント留置により吻合 血管の位置を確認した上で後腹膜腔の展開を慎重

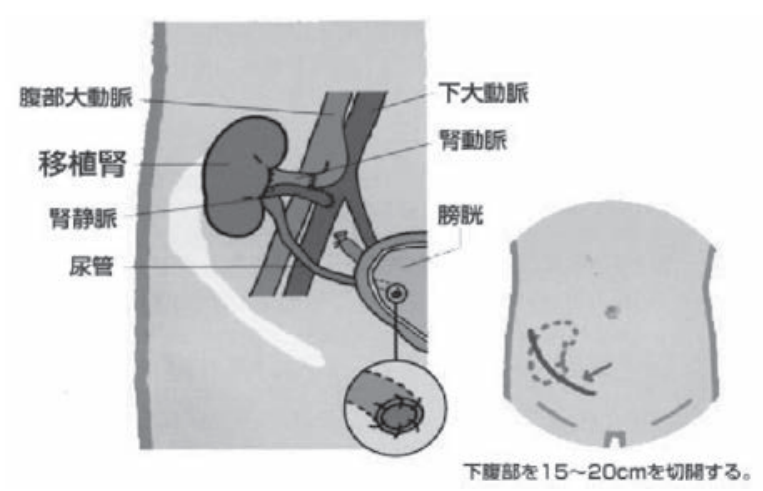

(日本腎臟学会、日本透析医学会、日本移植学会パンフレットより抜粋) 図6 腎臓移植手術
に行う工夫をしたとの報告 ${ }^{11)}$ や、後腹膜腔の展 開の際に移植腎の影響により鉗子が干渉しないよ う、術前にポート位置について慎重に検討し工夫 したとの報告がある ${ }^{12)}$ 。また良性腫瘍に対する子 宮全摘術でも巨大な子宮筋腫や腺筋症の症例では 術前にGnRHアゴニストを使用し腫瘍の縮小をは かり、ポートの配置や鉗子の操作を容易にする工 夫をしたという報告がある ${ }^{13)}$ 。さらに、癒着が予 測されるような症例では癒着の評価およびポート の位置の決定のために術中に体表エコーを用いて 評価を行うといった工夫や ${ }^{14)}$ 、術前に尿管の走行 を正確に把握するために尿管ステントを留置す る、経静脈性腎孟造影を施行するといった工夫が 報告されている ${ }^{15)}$ 。

\section{【結 語】}

今回われわれは 2 人の腎移植後の患者に対し、 腹腔鏡下卵巣腫瘍手術を施行した。普段われわれ が投与する機会はほとんどない免疫抑制剂の投与 方法は、腎移植外科医の指示を仰ぎながら決定し、 周術期の合併症はなく手術を完遂することができ た。腎移植後の患者に対し安全に腹腔鏡下手術を 行うためには、腎移植外科の医師との連携と、移 植腎が下腹部腸骨窩に存在していることに留意し た上で手術を行うことが必要であると考えられ た。

本論文の要旨は第 52 回日本産科婦人科内視鏡学 会で発表した。すべての著者は開示すべき利益相 反はない。

\section{【参考文献】}

1) 一般社団法人日本移植学会 臟器移植ファクトブッ ク 2018

www.asas.or.jp/jst/pdf/factbook/factbook2018.pdf (最終アクセス日 2020 年 2 月 24 日)

2 ) 日本移植学会・日本臨床腎移植学会: 腎移植臨床登 録集計報告（2019）2018年実施症例の集計報告と追 跡調査結果 $2019: 61-80$.

3 ) 日本TDM学会：日本移植学会：免疫抑制薬 TDM 標準化ガイドライン2018臟器移植編：22-27、金原出 版.

4) 倉田信彦、他：腎移植患者に発症した消化器癌3症例 における周術期管理の検討、日本消化器外科学会雑 誌、 $2016 ； 49$ (6) : 569-577.

5 ) 三鴨廣繁：婦人科領域における最小侵襲手術時代の 感染発症阻止化学療法、日本化学療法学会雑誌、 $2002 ; 50: 589-592$. 
6) 日本神経治療学会：神経免疫疾患治療ガイドライン 標準的神経治療 神経 免疫疾患に使用される免疫抑 制剂の作用機序と一般的副作用 www.jsnt.gr.jp/ guideline/img/meneki_8.pdf（最終アクセス日2020年 3 月16日）

7 ）じん臓病診療の最先端 VOL22 第 2 章：腎移植療法 の基本戦略Jizou.net http://www.jinzou.net/01/pro/ sentan/vol_22/p2.html （最終アクセス日2020年 3 月 6 日）

8 ）腎不全 治療選択とその実際、2019、日本腎臟学会· 日本透析医学会・日本移植学会・日本臨床腎移植学会· 日本腹膜透析医学会 www.jsn.or.jp/academicinfo/ sbook.php（最終アクセス日2020年 2 月24日）

9 ) 武田哲、炭谷崇義：腎移植後に単孔式で行った腹腔 鏡下異所性妊娠手術 日本産科婦人科内視鏡学会雑誌 2015 31(1): 218-221.

10）宮内亘、他：単孔式腹腔鏡下開空術を施行した腎移 植後リンパ囊腫の例 鳥取医学雑誌 2017 45(1): 30-32.

11）角田守、他：腎移植後患者に対して、腹腔鏡下準広 沉子宮全摘術を行った一例 産婦人科手術2015. (26): 165-165.

12）二村涼、他：腎移植後の子宮頚部腺癌に対してロボ ット支援腹腔鏡下単純子宮全摘術を施行した 1 例. 日本産科婦人科内視鏡学会雑誌 2018 34: 214.

13) Chen Sy. et al.: Laparoscopic Assisted Vaginal Hysterectomy Following Previous Kidney Transplantation. Taiwan J Obstet Gynecol 2009: 48(3): 249-253.

14) Kakuda M. et al.: Total laparoscopic hysterectomy for endometrial cancer in a renal transplantation patient receiving peritoneal dialysis: Case report and literature review.J Obstet Gynaecol Res. 2017; 43(7): 1232-1237.

15）貴島雅子、他：生体腎移植後に腹腔鏡手術を行った 2 症例 日本産科婦人科内視鏡学会雑誌 2018 34(1): 153-158.

投稿日：2020年 4 月 15 日 採択日：2020年 8 月 2 日 